\title{
DETECTION OF CHANGE IN DROUGHT FREQUENCY IN BYDGOSZCZ REGION, CENTRAL POLAND
}

\author{
Renata KUŚMIEREK-TOMASZEWSKA, Department of Land Reclamation and Agrometeorology, Faculty of Agriculture and \\ Biotechnology, UTP University of Science and Technology, ul. Bernardyńska 6, 85-029 Bydgoszcz, Poland, rkusmier@utp.edu.pl \\ (corresponding author) \\ Stanislaw DUDEK, Department of Land Reclamation and Agrometeorology, Faculty of Agriculture and Biotechnology, UTP \\ University of Science and Technology, ul. Bernardyńska 6, 85-029 Bydgoszcz, Poland, dudek@utp.edu.pl \\ Jacek ŻARSKI, Department of Land Reclamation and Agrometeorology, Faculty of Agriculture and Biotechnology, UTP University \\ of Science and Technology, ul. Bernardyńska 6, 85-029 Bydgoszcz, Poland, zarski@utp.edu.pl
}

\begin{abstract}
The aim of the work, carried out within the framework of research on currently occurring rather than predicted climate changes, was to confirm or deny the hypothesis of increasing incidence of droughts in central Poland (the Bydgoszcz region) over the years 1986-2015. According to projections of climate change, the variability and extremity of weather conditions are expected to increase. In studies conducted under some climate scenarios, it was shown that atmospheric precipitation variability in central Poland will increase even to $20 \%$, depending on the scenario. Some researches indicate that these changes are already taking place. The material was the data of precipitation measurements gained from weather station, located in a poorly urbanized area, at the Research Center of the University of Science and Technology. Totals of atmospheric precipitation in the 30-year period were analyzed (1986-2015). Dry periods in individual months, seasons, half-years and entire years were identified on the basis of the relative precipitation index (RPI). The precipitation totals in the years 1986-2015 were characterized by a very high temporal variability and thus increased the climatic risk of plants cultivation. The significant positive trend of precipitation totals was found only for the cold half-year, which is consistent with the projections of the IPCC report. The frequency of the occurrence dry months was $38.6 \%$, of seasons $38.3 \%$, half-years $35.0 \%$ and years $30.0 \%$. There was noted no increasing frequency of dry periods with years; just to the contrary, a decreasing tendency was identified.
\end{abstract}

Keywords: atmospheric precipitation, climate change, drought, relative precipitation index

\section{INTRODUCTION}

A characteristic feature of the temperate transitional climate of central Poland is a high variation in weather conditions in the same calendar periods of respective years. It mostly refers to precipitation, resulting in the occurrence of long-term droughts and the periods with excessive moisture, leading to local inundations and floods (Labędzki, 2006, Żarski et al., 2013, 2017). As it is seen from the climate change projections, a variation and extreme character of weather conditions is to increase. In the simulation study, performed compliant with typical climate change scenarios, GISS Model E, HadCM3 and GFDL R15, it has been shown that in central Poland there will be an increase in precipitation variation up to 20 percent, depending on the scenario. It means a greater risk of droughts and a need to ensure the coverage of increased water requirements in plants over the vegetation period (Kuchar and Iwański, 2013). Some research demonstrate that those changes have been occurring already. Somorowska (2009) found in the last two decades of the $20^{\text {th }}$ century an occurrence of an increased number of dry months in most of the regions of Poland analyzed. Similar conclusions are reported by Jania and Zwoliński (2011), Skowera (2014), Wibig (2012) and Ziernicka-Wojtaszek (2015). However, according to Czarnecka and Nidzgorskiej-Lencewicz (2012), multi-year changes in the amount of the seasonal precipitation in the 60-year period; 1951-2010, do not show in Poland a significant linear trend. Non-significant are also common opinions about a growing variation in precipitation. The study by Marsz et al. (2016) shows that the frequency of occurrence of droughts over Poland depends on the circulation factors and it is greater over the period of an increased intensity of Thermohaline Circulation THC, at "warm" North Atlantic phases.

The aim of this research, performed as part of research of the current and unexpected climate changes, except for defining general characteristics of precipitation conditions for central Poland, has been to confirm or to deny the hypothesis about a growing frequency of the drought occurrence in the Bydgoszcz region in the multi-annual period from 1986 to 2015.

Copyright (C) 2017 The Authors. Published by Aleksandras Stulginskis University. This is an open-access article distributed under the terms of the Creative Commons Attribution License (CC-BY 4.0), which permits unrestricted use, distribution, and reproduction in any medium, provided the original author and source are credited. 


\section{MATERIAL AND METHODS}

The material was made up of the results of the precipitation measurements, performed following a standard procedure at the Research Center of the UTP University of Science and Technology in Bydgoszcz, located at Mochełek, about $20 \mathrm{~km}$ away from the city center $\left(\phi^{\prime}=53^{\circ} 13^{\prime} \mathrm{N}, \lambda=17^{\circ} 51^{\prime} \mathrm{E}, \mathrm{h}=98.5 \mathrm{~m}\right.$ above sea level) in the area poorly urbanized and industrialized. It is a measurement point free from the effect of urban anthropogenic factors representative for the Bydgoszcz region, acting continuously since 1949. To ensure the homogeneity of the measurement series, acting compliant with the WMO guidelines, the paper analyzes only total precipitation over the 30-year (1986-2015) period. Even though prolonging the series increases the analytical material and creates greater possibilities of drawing conclusions, still the risk of a failure to comply with, fundamental in this research, the principle of comparability of the results of meteorological measurements and observations is much greater. It can lead to faulty conclusions due to a failure to meet the condition of the comparability of the place of measurements, measurement instruments or procedures of data averaging (Kuśmierek et al., 2012).

Dry months, seasons, half-years and years were identified based on the Relative Precipitation Index (RPI) which refers to the total precipitation in a given period of a specific year to the mean multi-annual value of a given year (Łabędzki, 2006). Drought classes according to that index are broken down in Table 1.

Statistical methods commonly applied in climatological elaborations (Garnier, 1996) have been applied. The trends method with linear regression equations turned out especially applicable to the 30 -year measurement period. To determine a potential increase in the variation of precipitation in time, coefficients of variation $(\mathrm{CV})$ for precipitation in the initial period of the $21^{\text {st }}$ century (2001-2015) were compared to the final 15.years of the $20^{\text {th }}$ century (1986-2000). The method was applied in reference to dry months, seasons, half-years and years.

Table 1. Drought classes according to Relative Precipitation Index (RPI) (Łabędzki and Bąk, 2004)

\begin{tabular}{|l|c|c|}
\hline Class of drought & RPI in month & RPI in season, half-year or year \\
\hline Extremely dry & $0.0-24.9 \%$ & $0.0-49.9 \%$ \\
\hline Very dry & $25.0-49.9 \%$ & $50.0-74.9 \%$ \\
\hline Dry & $50.0-74.9 \%$ & $75.0-89.9 \%$ \\
\hline
\end{tabular}

\section{RESULTS AND DISCUSSION}

The 1986-2015 precipitation multi-year averages in respective months, seasons (April III-V, Summer VI-VIII, Autumn IX-XI, Winter XII-II), half-years and years, in general, comply with the studies performed so far based on other multi-annual periods (Czarnecka and Nidzgorska-Lencewicz, 2012, Łabędzki, 2006, Żarski et al., 2014). The mean multiyear annual total of $491.2 \mathrm{~mm}$ (Table 2) allows for considering the Bydgoszcz region as representing the areas of the lowest precipitation in Poland. The feature of the precipitation of the Bydgoszcz region and central Poland, characteristic for the continental-type distribution, is a dominance of warm half-year precipitation (63.3\% of the annual total), as compared with the cold half-year (36.7\% of the annual total). Of all the seasons the highest mean precipitation totals are noted in summer and the lowest in winter. The month with the highest precipitation totals is July, followed by August and June.

Table 2. Multi-year mean (1986-2015) atmospheric precipitation totals in the Bydgoszcz region together with statistics defining the tendencies of changes with time and temporal variability

\begin{tabular}{|c|c|c|c|c|c|}
\hline Months/Periods & $\begin{array}{l}\text { Precipitation totals } \\
(\mathrm{mm})\end{array}$ & $\begin{array}{c}\text { Change in } 10 \text { years } \\
(\mathrm{mm})\end{array}$ & $\begin{array}{c}\text { Linear correlation } \\
\text { coeff. }\end{array}$ & $\begin{array}{c}\text { Coeff. of variation } \\
1986-2000(\%)\end{array}$ & $\begin{array}{c}\text { Coeff. of variation } \\
2001-2015(\%)\end{array}$ \\
\hline I & 28.5 & 5.0 & 0.246 & 64 & 58 \\
\hline II & 21.8 & 2.4 & 0.169 & 51 & 61 \\
\hline III & 31.9 & 1.6 & 0.089 & 53 & 49 \\
\hline IV & 26.9 & -0.1 & -0.001 & 57 & 64 \\
\hline $\mathrm{V}$ & 50.2 & 10.6 & 0.303 & 69 & 55 \\
\hline VI & 54.9 & -2.1 & -0.059 & 48 & 68 \\
\hline VII & 71.4 & 14.9 & 0.351 & 59 & 44 \\
\hline VIII & 59.7 & 4.5 & 0.113 & 45 & 65 \\
\hline IX & 47.5 & -4.0 & -0.126 & 57 & 62 \\
\hline $\mathrm{X}$ & 30.6 & 1.6 & 0.057 & 62 & 87 \\
\hline XI & 32.7 & 2.2 & 0.094 & 49 & 71 \\
\hline XII & 35.0 & 1.4 & 0.077 & 44 & 51 \\
\hline I-XII & 491.2 & 38.1 & 0.328 & 18 & 20 \\
\hline IV-IX & 310.7 & 23.9 & 0.253 & 26 & 26 \\
\hline X-III & 180.5 & 16.5 & $0.361^{1}$ & 29 & 12 \\
\hline III-V & 109.0 & 12.2 & 0.290 & 34 & 33 \\
\hline VI-VIII & 186.1 & 17.3 & 0.242 & 34 & 32 \\
\hline IX-XI & 110.8 & -0.2 & 0.000 & 36 & 41 \\
\hline XII-II & 86.1 & 8.8 & 0.275 & 33 & 31 \\
\hline
\end{tabular}

${ }^{1}$ significant dependence at $\alpha=0.05$ 
Precipitation in the Bydgoszcz region in 1986-2015 showed a very high temporal variability, characteristic for the climate of central Poland. With the coefficients of variation, one can state that the highest temporal variability was reported for October and the lowest - for December. A higher precipitation variation was noted for the warm half-year, as compared with the cold half-year, and as for the seasons - the most variable was the precipitation in autumn. A comparison of the coefficients of variation of the precipitation totals in 1986-2000 and 2001-2015 revealed that in some cases (e.g. in October, June and August) a higher variation in precipitation concerned the years 2001-2015. In other time steps (e.g. in May, July and cold half-year) the precipitation totals in 1986-2000 were more varied. All that does not allow for a definite determination that the temporal variability of the precipitation totals in 2001-2015 gets bigger, as compared with the previous 15 years. It is compliant with the conclusions by Czarnecka and Nidzgorska-Lencewicz (2012) who, drawing on a comprehensive analysis of Poland's precipitation conditions, did not state an increasing precipitation variation.

The precipitation totals did not reveal, in 18 out of 19 time steps analyzed, any significant changes with years from 1986 to 2015 (Table 2). In most cases there was a tendency of growing precipitation. A significant trend of increasing precipitation totals from 1986 to 2015 was recorded only for the cold half-year (X-III). The trend is compliant with IPCC projections (2014).

The total number of months determined compliant with RPI as extremely dry, very dry and dry, which occurred in the 1986-2015 multi-year period, was 139 out of 360 (30 years x 12 months) (Table 3). It means the occurrence frequency of $38.6 \%$. The highest frequency was recorded for dry $(20.0 \%)$, lower - very dry $(13.1 \%)$, and the lowest extremely dry months $(5.5 \%)$. As for respective months, one can state the highest number of dry Octobers (16 out of 30$)$ and Aprils (14 out of 30), and the lowest number of Augusts and Decembers (9 each out of 30 analyzed).

Table 3. The 1986-2015 total number of the dry months and periods identified in the Bydgoszcz region

\begin{tabular}{|c|c|c|c|c|c|c|}
\hline \multirow[t]{2}{*}{ Months/Periods } & \multirow[t]{2}{*}{ Extremely dry } & \multirow[t]{2}{*}{ Very dry } & \multirow[t]{2}{*}{ Dry } & \multicolumn{3}{|c|}{ In total } \\
\hline & & & & $1986-2015$ & 1986-2000 & $2001-2015$ \\
\hline I & 2 & 4 & 6 & 12 & 7 & 5 \\
\hline II & 1 & 4 & 7 & 12 & 7 & 5 \\
\hline III & 2 & 4 & 4 & 10 & 5 & 5 \\
\hline IV & 1 & 3 & 10 & 14 & 7 & 7 \\
\hline $\mathrm{V}$ & 4 & 4 & 2 & 10 & 6 & 4 \\
\hline VI & 0 & 5 & 8 & 13 & 5 & 8 \\
\hline VII & 2 & 4 & 5 & 11 & 7 & 4 \\
\hline VIII & 1 & 5 & 3 & 9 & 4 & 5 \\
\hline IX & 1 & 6 & 4 & 11 & 5 & 6 \\
\hline $\mathrm{X}$ & 4 & 4 & 8 & 16 & 7 & 9 \\
\hline XI & 0 & 3 & 9 & 12 & 6 & 6 \\
\hline XII & 2 & 1 & 6 & 9 & 3 & 6 \\
\hline Months in total & 20 & 47 & 72 & 139 & 69 & 70 \\
\hline I-XII & 0 & 4 & 5 & 9 & 6 & 3 \\
\hline IV-IX & 2 & 3 & 4 & 9 & 5 & 4 \\
\hline X-III & 1 & 2 & 9 & 12 & 10 & 2 \\
\hline III-V & 2 & 8 & 0 & 10 & 6 & 4 \\
\hline VI-VIII & 2 & 4 & 7 & 13 & 8 & 5 \\
\hline IX-XI & 2 & 8 & 2 & 12 & 6 & 6 \\
\hline XII-II & 1 & 6 & 4 & 11 & 7 & 4 \\
\hline Periods in total & 7 & 26 & 13 & 46 & 27 & 19 \\
\hline
\end{tabular}

As for the half-years, more dry half-years were cold (12) and fewer - warm (9) and as for the seasons, the number of the periods defined as dry ranged from 10 (springs) to 13 (summers). In total there were noted 46 dry seasons (out of the 120 seasons analyzed), which stands for the frequency of $38.3 \%$.

A comparison of the frequency of occurrence of the months defined as extremely dry, very dry and dry in 19862000 and 2001-2015 shows that, in general, the frequency was almost identical (Table 3). On the other hand, as for the seasons, more dry (27) seasons occurred in the first 15 years, as compared with 2001-2015 (19). Also in the case of the entire years and half-years (especially the cold half-year), one can note a greater frequency of dry periods in the last 15 years of the $21^{\text {st }}$ century.

The analysis of trends has shown a decreasing tendency of the occurrence of all the dry months (namely extremely dry, very dry and dry) with years from 1986 to 2015 (Figure 1). Similarly a total number of the most perceived months being extremely dry and very dry was decreasing (Figure 2). One cannot thus state a more and more frequent occurrence of droughts in central Poland in the last 30 years.

Similar research was carried out by Taparauskienè and Lukševičiūtėa (2015) for Lithuanian climatic conditions during the period of 1982-2014. Drought occurrences were determined by the SPI index. According to obtained results, the authors stated that, droughts occurred in $14.5 \%$ of all analyzed months in Kaunas region, while in region of Telšiai this phenomenon occurred in $15.8 \%$ respectively. Under climatic conditions of Lithuania the probability for extremely dry period occurrence is quite low ( $\mathrm{p}-0.03$ ). The probability of severely dry period occurrence is not higher than 0.05 , and moderately dry not higher than 0.08 . The authors found, that the highest probability is for moderately wet conditions $\mathrm{p}-0.36$ in Kaunas region and $\mathrm{p}-0.34$ in Telšiai region. 


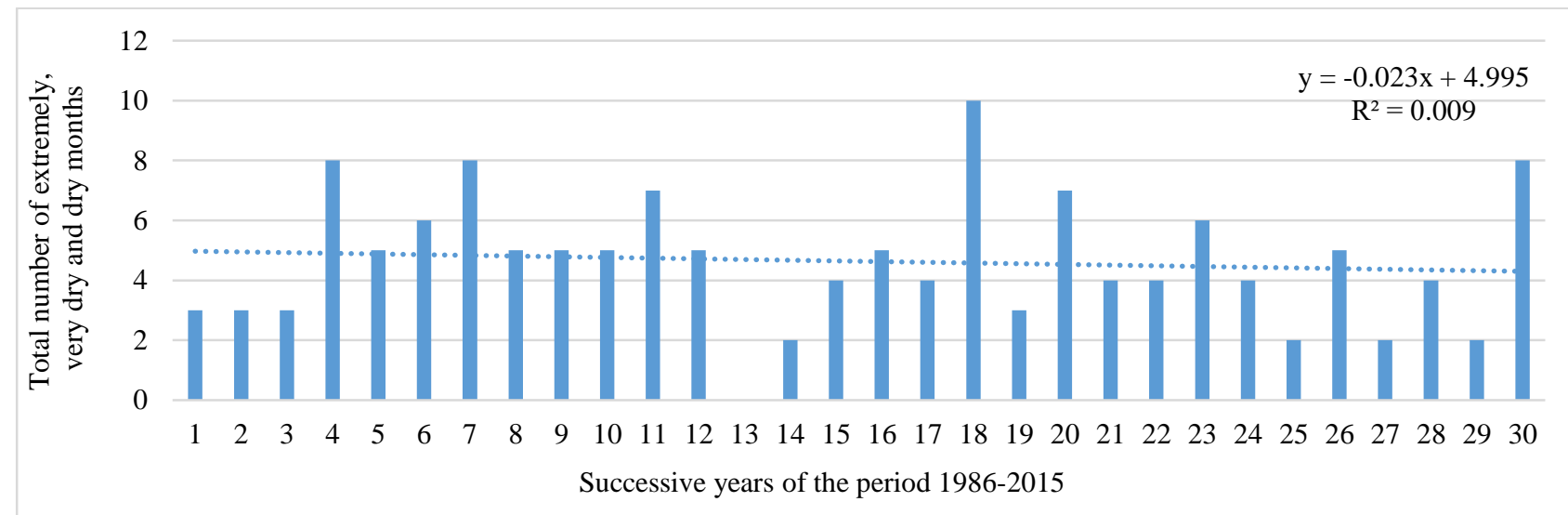

Figure 1. Occurrence of extremely dry, very dry and dry months in the successive years of the 1986-2015 period with a tendency

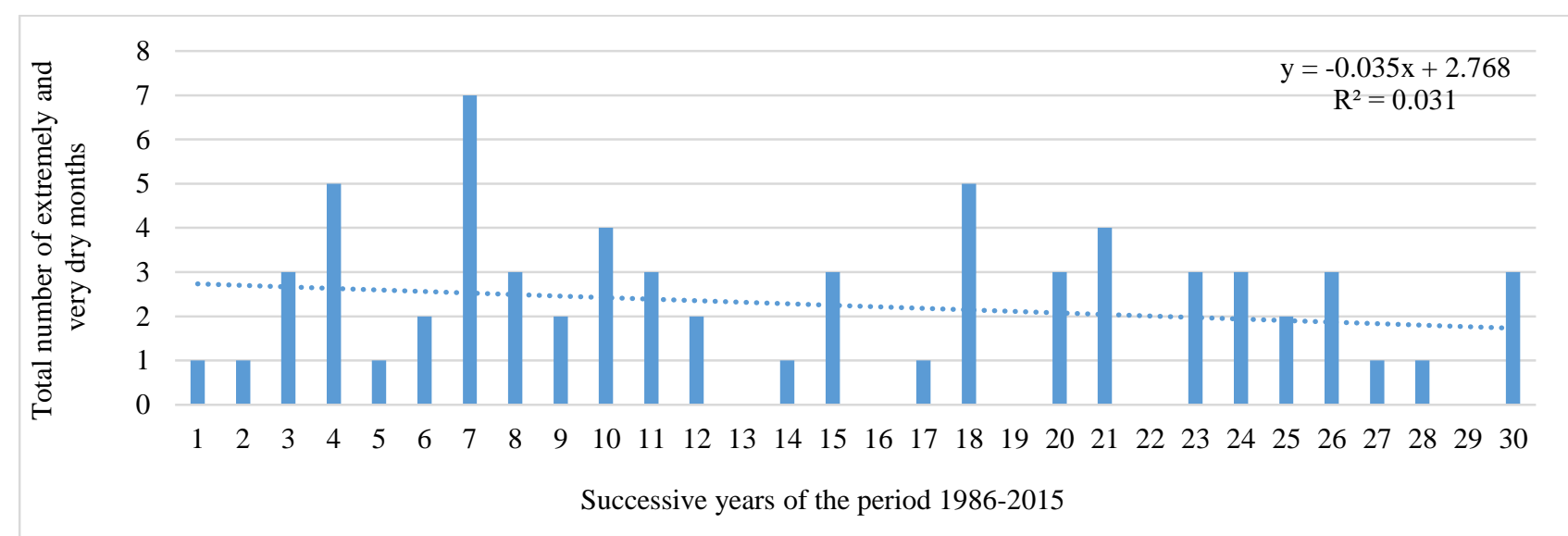

Figure 2. Occurrence of extremely dry and very dry months in the successive years of the 1986-2015 period with a tendency

\section{CONCLUSIONS}

The 1986-2015 multi-year precipitation averages in respective months, seasons, half-years and the entire years, in general, compliant with the reports so far, allow for considering the Bydgoszcz region as the areas with the lowest precipitation in Poland.

Precipitation in the Bydgoszcz region in 1986-2015 showed a very high temporal variability, resulting in a climate risk posed to the cultivation of plants. There was found no definite extension of the temporal variability of the 2001-2015 precipitation totals, as compared with the period 1986-2000. A significant trend of increasing precipitation totals in the period from 1986 to 2015 was reported only in reference to the cold half-year, which complies with the IPCC projections.

The frequency of the occurrence of extremely dry, very dry and dry months in the Bydgoszcz region accounted for $38.6 \%$, seasons - for $38.3 \%$, half-years - for $35.0 \%$ and years - for $30.0 \%$. There was noted no increasing frequency of those dry periods with years from 1986 to 2015 ; just to the contrary, a decreasing tendency was identified.

\section{REFERENCES}

1. Czarnecka, M., Nidzgorska-Lencewicz, M. 2012. Wieloletnia zmienność sezonowych opadów w Polsce. Woda-ŚrodowiskoObszary Wiejskie, Vol. 12, Iss. 2(38), pp. 45-60. [In Polish]

2. Garnier B.J. 1996. Podstawy klimatologii. IMGW Press, Warszawa. [In Polish]

3. IPCC. 2014. AR5 Synthesis Report - Climate Change 2014. Available at https://www.ipcc.ch/pdf/assessmentreport/ar5/syr/SYR_AR5_FINAL_full_wcover.pdf (Accessed on 18/09/2017)

4. Jania, J.A., Zwoliński, Z. 2011. Ekstremalne zdarzenia meteorologiczne, hydrologiczne i geomorfologiczne w Polsce. Landform Analysis, Vol. 15, pp. 51-64. [In Polish]

5. Kuchar, L., Iwański, S. 2013. Ocena opadów atmosferycznych dla potrzeb produkcji roślinnej w perspektywie lat 2050-2060 i wybranych scenariuszy zmian klimatu w północno centralnej Polsce. Infrastruktura i Ekologia Terenów Wiejskich, No. 2/I, pp. 187-200. [In Polish]

6. Kuśmierek-Tomaszewska. R., Żarski. J., Dudek. S. 2012. Meteorological automated weather station data application for plant water requirements estimation. Computers and Electronics in Agriculture, Vol. 88, pp. $44-51$. https://doi.org/10.1016/j.compag.2012.07.002

7. Łabędzki, L., 2006. Susze rolnicze. Zarys problematyki oraz metody monitorowania i klasyfikacji. IMUZ, Falenty. [In Polish] 
8. Łabędzki, L., Bąk, B. 2004. Standaryzowany klimatyczny bilans wodny, jako wskaźnik suszy. Acta Agrophysica, Vol. 3, No. 1, pp. 117-124. [In Polish]

9. Marsz, A. A., Styszyńska, A., Krawczyk, W.E. 2016. Długookresowe wahania przepływów rocznych głównych rzek w Polsce i ich związek z cyrkulacją termohalinową Atlantyku Północnego. Przegląd Geograficzny, Vol. 88, No. (3), pp. $295-316$. https://doi.org/10.7163/PrzG.2016.3.1 [In Polish]

10. Somorowska, U. 2009. Wzrost zagrożenia suszą hydrologiczną w różnych regionach geograficznych Polski w XX wieku. Prace $i$ Studia Geograficzne, No. 43, pp. 97-114. [In Polish]

11. Skowera, B. 2014. Zmiany warunków hydrotermicznych na obszarze Polski (1971-2010). Fragmenta Agronomica, Vol. 31, Iss. 2, pp. 74-87. [In Polish]

12. Taparauskienè L., Lukševičiūtė V. 2015. Drought occurrence under Lithuanian climatic conditions. Proceedings of the 7th International Scientific Conference "Rural Development 2015". Towards the Transfer of Knowledge, Innovations and Social ProgressAleksandras Stulginskis University, pp. 1-4. https://doi.org/10.15544/RD.2015.059

13. Wibig, J. 2012. Warunki wilgotnościowe w Polsce w świetle wskaźnika standaryzowanego klimatycznego bilansu wodnego. Woda-Środowisko-Obszary Wiejskie, Vol. 12, No. 2(38), pp. 329-340. [In Polish]

14. Ziernicka-Wojtaszek, A. 2015. Klimatyczny bilans wodny na obszarze Polski w świetle współczesnych zmian klimatu. WodaŚrodowisko-Obszary Wiejskie, Vol. 15, Iss. 4(52), pp. 93-100. [In Polish]

15. Żarski, J., Dudek, S., Kuśmierek-Tomaszewska, R., Rolbiecki, R., Rolbiecki, S. 2013. Prognozowanie efektów nawadniania roślin na podstawie wybranych wskaźników suszy meteorologicznej i rolniczej. Annual Set The Environment Protection, Vol. 15, pp. 2185-2203. [In Polish]

16. Żarski, J., Dudek, S., Kuśmierek-Tomaszewska, R., Bojar, W., Knopik, L., Żarski, W. 2014. Agroklimatologiczna ocena opadów atmosferycznych okresu wegetacyjnego w rejonie Bydgoszczy. Infrastruktura i Ekologia Terenów Wiejskich II/3, pp. 643-656. http://dx.medra.org/10.14597/infraeco.2014.2.2.047 [In Polish]

17. Żarski, J., Dudek, S., Kuśmierek-Tomaszewska, R., Żarski, W. 2017. Effects of agricultural droughts in the province of KujawskoPomorskie and possibilities of minimizing their impact. Infrastructure and Ecology of Rural Areas, II/2/2017, pp. 813-824. http://dx.medra.org/10.14597/infraeco.2017.2.2.063 